\title{
Antimicrobial Potential and Chemical Profiling of Leaves Essential Oil of Mentha Species Growing under North-West Himalaya Conditions
}

\author{
Sonam ${ }^{1}$, Amita Kumari ${ }^{1 *}$ (D) , Vikas Kumar ${ }^{2}$, Ishita Guleria ${ }^{1}$, Mamta Sharma ${ }^{1}$, \\ Ashwani Kumar ${ }^{3 *}$ (D), Mashael W. Alruways ${ }^{4}$, Nazam Khan ${ }^{4}$ and Ravinder Raina ${ }^{5}$ \\ ${ }^{1}$ School of Biological and Environmental Sciences, Shoolini University, Solan-173 212, Himachal Pradesh, India. \\ ${ }^{2}$ School of Biotechnology, Shoolini University, Solan-173 212, Himachal Pradesh, India. \\ ${ }^{3}$ Patanjali Herbal Research Department, Patanjali Research Institute, Haridwar-249 405, Uttarakhand, India. \\ ${ }^{4}$ Department of Clinical Laboratory Sciences, College of Applied Medical Sciences, Shaqra University, \\ Shaqra, Saudi Arabia. \\ ${ }^{5}$ Amity Food and Agriculture Foundation, Amity University, Noida-201 313, Uttar Pradesh, India.
}

\begin{abstract}
Mentha essential oil is one of the most utilized essential oil in the food and pharmaceutical industries. The present study reports the chemical composition and antibacterial properties of leaf essential oils of Mentha species. Further, the effect of the harvesting period on essential oil yield was also investigated. Firstly, the cultivated Mentha piperita and wild Mentha longifolia, revealed significant differences in their chemical profile. M. longifolia essential oil was characterized with endo-borneol (1.12-6.2\%), caryophyllene (2.72-7.03\%), isopipertenone (0.07-0.36\%), germacrene $D(0.98-3.22 \%)$, 3-cyclopentene1-one,2-hydroxy-3-(3-methyl-2-butenyl)- (21.91-56.72\%) and piperitone oxide (8.96-39.31\%), whereas, M. piperita leaves essential oil was found rich in isomenthone (5.97-6.75\%), 1-menthone (7.32-18.32\%) and menthol (18.03-58.53\%), etc. The essential oils of both Mentha species exhibited strong antimicrobial activity as evaluated using poisoned food technique, dry weight method, and disc diffusion method against Candida albicans, Fusarium oxysporum, Bacillus subtilis, Staphylococcus aureus, Klebsiella pneumoniae and Escherichia coli. Secondly, the maximum essential oil yield was observed in July month, $0.63 \pm 0.01$ and $0.56 \pm 0.01 \%$, respectively for $M$. piperita and $M$. longifolia.
\end{abstract}

Keywords: Disc diffusion method, Poisoned food technique, Harvesting period, Gas chromatography-mass spectrometry

*Correspondence: amitabot@gmail.com; ashu5157@gmail.com; +91 9418409295

(Received: June 18, 2021; accepted: October 11, 2021)

Citation: Sonam, Kumari A, Kumar V, et al. Antimicrobial Potential and Chemical Profiling of Leaves Essential Oil of Mentha Species Growing under North-West Himalaya Conditions. J Pure Appl Microbiol. 2021;15(4):2229-2243. doi: 10.22207/JPAM.15.4.45

(C) The Author(s) 2021. Open Access. This article is distributed under the terms of the Creative Commons Attribution 4.0 International License which permits unrestricted use, sharing, distribution, and reproduction in any medium, provided you give appropriate credit to the original author(s) and the source, provide a link to the Creative Commons license, and indicate if changes were made. 


\section{INTRODUCTION}

Mentha is one of the most important genera of the Lamiaceae family, and its medicinal and aromatherapeutic effects have been known since ancient times. ${ }^{1}$ It is made up of about 25-30 species that are found in Asia, Africa, Australia, Europe, and North America. ${ }^{2}$ M. piperita L. and $M$. longifolia $L$. are two of the most important medicinal plant species in terms of ethnobotanical significance among these species.

$M$. longifolia, often known as wild mint, is a plant native to Africa, Europe, and Asia that has long been traditionally used to cure bronchitis, nausea, anorexia, flatulence, ulcerative colitis, and liver problems. ${ }^{3,4}$ The antioxidant, anti-inflammatory, antimicrobial, analgesic, stimulant, carminative, diaphoretic, antiemetic, antispasmodic, anticatarrhal, emmenagogue, and anticarcinogenic properties have also been documented for the species. ${ }^{2,3}$ M. piperita L., commonly known as peppermint, is a popular tonic herb and flavoring ingredient. It is a sterile hybrid from a cross between spearmint ( $M$. spicata) and water mint (M. aquatica). ${ }^{5}$ In the past, headache, migraine, vomiting, bronchitis, menstrual cramps, and digestive diseases like irritable bowel syndrome and constipation have all been treated with this species. ${ }^{6}$ Additionally, this species also exhibit astringent, antiseptic, antipyretic, analgesic, anticarcinogenic, antioxidant, and antispasmodic property. ${ }^{7}$

All these medicinal properties in Mentha species are due to the presence of essential oil, a complex mixture of low molecular weight volatile compounds. It is a product of secondary metabolism. ${ }^{8}$ In folk medicine, essential oils have been used for treating various ailments such as joint swelling, skin diseases, cuts, and wounds. ${ }^{9,10}$ They demonstrated antibacterial, antiviral, antioxidant, insecticidal, and other biological effects. ${ }^{10}$ Interestingly, these essential oils are also utilized in the treatment of cancer. ${ }^{11}$ Further, they have a wide range of therapeutic applications, including food preservation, pharmaceuticals, and alternative treatments. ${ }^{11,12} \mathrm{M}$. longifolia essential oil was found rich in pulegone, carvone, piperitone, menthone, menthol, Isomenthone, 1,8-Cineole, while menthol, menthone, menthyl acetate, menthofuran, piperitinone oxide,
$\alpha$-Terpinene, carveol, etc. constitute the bioactive composition of M. piperita. ${ }^{13}$

Secondary metabolites (alkaloids, phenols, flavonoids, and so on) have therapeutic characteristics; their production and accumulation are influenced by the genotype as well as the plant's interaction with its environment. The photoperiod, temperature, relative humidity, and other climatic conditions influence the chemical profile because some chemicals accumulate over time in response to environmental changes. ${ }^{14}$ The plant secondary metabolite products are also affected by harvesting time, plant age, and crop density. ${ }^{15} \mathrm{As}$ a result, it is critical to understand the appropriate time and age for plants to have a rich chemical profile with robust biological activities, so they may be used for essential oil extraction and medicine development against deadly infections in the long run.

The researchers in India, ${ }^{16}$ Saudi Arabia, ${ }^{17}$ Turkey, ${ }^{18}$ Serbia, ${ }^{19}$ and others have previously identified seasonal change in the phytochemical content and biological properties of essential oils in both Mentha species. The motive of this study was to analyze the chemical profiles of essential oils from $M$. piperita and $M$. longifolia leaves harvested in the northwestern Himalaya, as well as to look into their antibacterial efficacy against pathogenic bacterial strains (Escherichia coli, Bacillus subtilis, Klebsiella pneumoniae, and Staphylococcus aureus) and fungi (Fusarium oxysporum and Candida albicans)

\section{MATERIAL AND METHODS \\ Plant collection}

In April-July 2018, $100 \mathrm{~g}$ leaves of cultivated $M$. piperita and wild M. longifolia were harvested from Y.S. Parmar University, Nauni, Solan nursery $\left(30^{\circ} 85^{\prime} 70^{\prime \prime} \mathrm{N}, 77^{\circ} 16^{\prime} 74^{\prime}\right.$ E) and Giripul (Distt. Sirmour; $30^{\circ} 52^{\prime} 53^{\prime} \mathrm{N}, 77^{\circ} 12^{\prime} 37^{\prime \prime} \mathrm{E}$ ), Himachal Pradesh, India, respectively, for the extraction of essential oil. The leaves were randomly sampled from the growing plot/area using a stratified random sampling method in the morning hours before noon for each month (April, May, June, and July).

\section{Identification of plants}

The Mentha species in the field were identified based on morphological characters 
(M. logifolia is characterized by ovate-lanceolate, greyish-green leaves with white hairs from the above, and purplish-white flowers, whereas in $M$. piperita leaves are ovate serrate, greencolored with long petiole, and purple flowers)..$^{20,21}$ Collected plants were further authenticated in the herbarium of Dr. Y.S. Parmar University of Horticulture and Forestry, Nauni, Solan, H.P., India. (UHF-Herbarium No. 13571). The voucher specimens have also been deposited in the herbarium of the School of Biological and Environmental Sciences, Shoolini University, Solan, H.P., India.

\section{Isolation of essential oil}

The leaves were harvested from plants (90 plants/3 quadrat) of $M$. piperita and $M$. longifolia and utilized for essential oil extraction using the hydrodistillation method. ${ }^{22}$ Briefly, fresh leaves (100 g) were chopped into bits and combined with distilled water (1 litre) in a flask. In continuation, Clevenger-type equipment was used to distil the mixture for 3 hours at $60^{\circ} \mathrm{C}$. The essential oil was extracted and stored at $4^{\circ} \mathrm{C}$ for further use.

\section{Essential oil yield}

Using the formula below, the essential oil yield in the percentage of each sample was computed:

$$
\text { Oil yield }=\frac{w 1}{w 2} \times 100
$$

Where, w1 = net weight of oil (g); w2 = total weight of fresh leaves (g)

\section{Gas chromatography-mass spectrometry analysis of leaves essential oil}

GC-MS analysis of $M$. piperita and $M$. longifolia leaves essential oil was performed as per the standard method of Okut et al. in the SERF laboratory of Punjab University, Chandigarh, India. ${ }^{23}$ The analysis was done using a GC-MS instrument (Thermo Trace $1300 \mathrm{GC}$ coupled with Thermo TSQ 8000 Triple Quadrupole MS) fitted with a TG 5MS capillary column (30 m x 0.25 $\mathrm{mm}$ i.d., $0.25 \mu \mathrm{m}$ film thickness) for qualitative determination. The essential oil was diluted $1 / 10$ in $n$-hexane $(\mathrm{v} / \mathrm{v})$ before analysis. The Autosampler was built for the injection of essential oils. The injector temperature was $250^{\circ} \mathrm{C}$. The temperature of the column was programmed from $60^{\circ} \mathrm{C}$ to $250^{\circ} \mathrm{C}$, held for $60^{\circ} \mathrm{C}$ for 2 minutes, moderately raised to $200^{\circ} \mathrm{C}$, and kept for 5 minutes with an increase of $15^{\circ} \mathrm{C} /$ minute to $220^{\circ} \mathrm{C}$. Helium was employed as a carrier gas with $1.5 \mathrm{~mL} /$ minutes flow rate, and mass spectra were taken in scan mode. The ionization voltage and split ratio were $70 \mathrm{eV}$ and 1:20, respectively. The ion source and interface were both at $230^{\circ} \mathrm{C}$ and $250^{\circ} \mathrm{C}$, respectively. The solvent cut time was 3 minutes. A total of $1.0 \mu \mathrm{l}$ of the sample was used in the analysis. The percentage of constituents was also determined using the response factor, and retention indexes (RIs) were calculated using the retention duration of n-alkanes (C10-C20) injected at the same temperature and under the same conditions. The phytoconstituents were identified by comparing their RI to those described in the literature, and by comparing their mass spectra to those recorded in the NIST 2.0 electronic library and the Wiley 275 libraries, with Match Factor (SI) and Reverse Match Factor (RSI) greater than 900. Antimicrobial activity

\section{Microbial strains and growth conditions}

To evaluate the antimicrobial potential, four bacterial [Gram positive bacteria (Bacillus subtilis (MTCC 5521) and Staphylococcus aureus (MTCC73) and Gram-negative bacteria (Escherichia coli (MTCC739) and Klebsiella pneumoniae (MTCC109))] and two fungal strains [Fusarium oxysporum (SR266-9), Candida albicans (ATCC90028) were selected. All microbial strains were procured from the Shoolini University's Yeast Biology and Plant Pathology laboratory. The bacteria were maintained on Nutrient Agar (NA) at $37^{\circ} \mathrm{C}$ for 18 to $24 \mathrm{~h}$. The fungal strain such as F. oxysporum was maintained on Potato Dextrose Agar (PDA) medium, while $C$. albicans was maintained on Yeast Peptone Dextrose Agar (YPD) media at $25^{\circ} \mathrm{C}$ for 48 to $72 \mathrm{~h}$.

Agar disc diffusion method

NA and YPD agar were spread with bacterial strains and yeast ( 0.5 McFarland standard), respectively. ${ }^{24,25}$ The $6 \mathrm{~mm}$ diameter discs of sterile filter paper soaked with various concentrations $(1.5-3.0 \mathrm{mg} / \mathrm{mL})$ of diluted essential oil (1:10 in DMSO, v/v) were kept on the inoculated plates. For positive control Ampicillin and Fluconazole $(50 \mu \mathrm{g} / \mathrm{mL})$ were used against tested bacterial and fungal strains, respectively. After the incubation period of $18-24 \mathrm{~h}$ at $37^{\circ} \mathrm{C}$ (in case of bacteria) and $48-72 \mathrm{~h}$ at $25^{\circ} \mathrm{C}$ (for fungi), inhibition zones were observed in the 
plates around the paper discs. An inhibition zone diameter was measured using HiMedia Zone scale. The experiment was carried out in triplicates.

\section{Poisoned food technique}

The leaves essential oils of both Mentha species (1:10 diluted in DMSO, v/v) at varying concentrations $(1.5-3.0 \mathrm{mg} / \mathrm{mL}$ ) were transferred to conical flasks containing $25 \mathrm{~mL}$ of sterilized PDA and then poured into Petri plates.

On the other hand, in the center of the Petri dish, 6-7 days old culture of F. oxysporum was placed and incubated at $25^{\circ} \mathrm{C}$. After seven days, the radial development of fungal mycelium was checked. The findings were compared with negative control (plates with DMSO only). ${ }^{26}$

The inhibition percentage of fungi in treatments was estimated using the formula below:

$$
\text { Percent inhibition }=\frac{\mathrm{C}-\mathrm{T}}{\mathrm{C}} \times 100
$$

Where $\mathrm{C}$ represents the colony radius in the control plate, and $\mathrm{T}$ represents the pathogen radial growth in the presence of essential oil.

\section{Dry weight method}

Briefly, five test tubes containing sterile potato dextrose broth $(5 \mathrm{~mL})$ were inoculated with actively growing $F$. oxysporum mycelium (20 $\mu \mathrm{L}$ containing $1 \times 10^{6}$ spores $/ \mathrm{mL}$ ) obtained from a 6-7 days old culture. In four test tubes, $20 \mu \mathrm{L}$ $(1.5-3.0 \mathrm{mg} / \mathrm{mL})$ of essential oil (1:10 in DMSO, v/v) was added, while one test tube was left without essential oil as a negative control, and all tubes were incubated at $25^{\circ} \mathrm{C}$ for 7 days. In the tubes, growth of visible mycelia represents the degree of effectivity of the essential oil. The fungal mycelia were further separated by filtration using Whatman filter paper No. 1. To achieve constant weight, the filter paper was dried at $60^{\circ} \mathrm{C}$.

The growth inhibition of fungi was calculated by observing the control and sample mycelial dry weight. ${ }^{27}$ The percentage growth inhibition was calculated using the following formula:

$$
\% \text { Growth inhibition }=\frac{\text { Control }- \text { Test }}{\text { Control }} \times 100
$$

\section{Minimum inhibitory concentration (MIC)}

The broth dilution method described by the Clinical and Laboratory Standards Institute was used for evaluating MIC. Briefly, essential oil was diluted geometrically (5-0.0095 \%) in a 96- well microtiter plate, having growth control (NB/ PDB/YPD broth containing DMSO) and positive control well (NB/PDB/YPD broth inoculated with each microbial culture and containing $10 \mathrm{mg} /$ $\mathrm{mL}$ of Ampicillin, Hygromycin B and Fluconazole separately). Further, an equal number of cells ( 2 $\times 10^{6} \mathrm{CFU} \mathrm{mL}-1,0.5 \mathrm{McF}$ arland) were inoculated into each well. At $37^{\circ} \mathrm{C}$ the microtiter plates were incubated for $24 \mathrm{~h}$ in case of bacteria and $25^{\circ} \mathrm{C}$ for $48 \mathrm{~h}$ in case of fungal strains. ${ }^{26,28}$ The 15 $\mu \mathrm{l}$ of the resazurin dye was added to each well and plate was further incubated for 2-4 hours at $37^{\circ} \mathrm{C}$. Any color changes after incubation period were observed. The blue color indicated bacterial growth whereas pink color indicated bacterial growth. Following the incubation period, the MIC values were reported as the lowest concentration of oil that suppresses observable microorganism growth. NB was used for antibacterial activity, while PDB and YPD Broth were used for antifungal activity.

\section{Data analysis}

Wherever necessary, analysis of variance (ANOVA), average and standard deviation were evaluated using GraphPad Prism 5.0. A p value $<0.05$ was considered statistically significant.

\section{RESULTS AND DISCUSSION \\ Essential oil yield}

In all harvesting months, there was a significant variation in the yield of peppermint and mint leaves essential oil with respect to the plant's harvesting age (Table 1 ). The results showed that the least essential oil yield was achieved in April $(0.26 \pm 0.02 \%$ and $0.63 \pm 0.01 \%$, respectively) and the maximum was achieved in July month

Table 1. The average essential oil yield (\%) of $M$. longifolia and $M$. piperita from April to July month in year 2018

\begin{tabular}{llr}
\hline Months & \multicolumn{2}{c}{ Essential oil content $(\% \pm \mathrm{SD})$} \\
& M. longifolia & M. piperita \\
\hline April & $0.24 \pm 0.01^{\mathrm{a}}$ & $0.26 \pm 0.02^{\mathrm{a}}$ \\
May & $0.40 \pm 0.02^{\mathrm{b}}$ & $0.45 \pm 0.01^{\mathrm{b}}$ \\
June & $0.49 \pm 0.02^{\mathrm{c}}$ & $0.58 \pm 0.01^{\mathrm{c}}$ \\
July & $0.56 \pm 0.01^{\mathrm{d}}$ & $0.63 \pm 0.01^{\mathrm{d}}$
\end{tabular}

[SD: Standard deviation; Different letters (a, b, c, d) were used when mean values were statistically different $(p<0.05)]$ 
Table 2. Phytocompounds observed in the essential oil from the leaves of M. piperita and M. longifolia (harvested during April-July, 2018)

\begin{tabular}{|c|c|c|c|c|c|c|c|c|}
\hline \multirow[t]{2}{*}{ No. } & \multirow[t]{2}{*}{ Compounds } & \multirow[t]{2}{*}{ RI (Obs) } & \multirow[t]{2}{*}{ RI (Lit) } & \multirow[t]{2}{*}{$\mathrm{RT}$} & \multicolumn{4}{|c|}{ Concentration (\%) } \\
\hline & & & & & April & May & June & July \\
\hline & & \multicolumn{7}{|c|}{ Mentha piperita } \\
\hline 1 & 1-Menthone & 1155 & 1150 & 5.57 & 7.32 & 12.69 & 18.32 & 13.24 \\
\hline 2 & Isomenthone & 1141 & 1148 & 5.69 & - & 6.53 & 5.97 & 6.75 \\
\hline 3 & Menthol & 1168 & 1165 & 5.89 & 58.42 & 51.05 & 18.72 & 18.03 \\
\hline 4 & Menthyl acetate & 1282 & 1291 & 6.98 & 4.78 & 6.35 & 6.89 & 0.72 \\
\hline 5 & Caryophyllene & 1408 & 1405 & 8.15 & 1.54 & 0.85 & 0.21 & 0.05 \\
\hline \multirow[t]{2}{*}{6} & Germacrene-D & 1475 & 1485 & 8.67 & 1.89 & 0.63 & 0.88 & 0.72 \\
\hline & \multicolumn{8}{|c|}{ Mentha longifolia } \\
\hline 1 & Endo-Borneol & 1154 & 1153 & 5.71 & 6.02 & 2.95 & 1.12 & 4.59 \\
\hline 2 & $\alpha$-Terpineol & 1178 & 1175 & 5.96 & - & 0.28 & 0.12 & 0.15 \\
\hline 3 & Piperitone oxide & 1218 & 1230 & 6.65 & 39.31 & 15.22 & 17.08 & 8.96 \\
\hline 4 & Carvone oxide & 1254 & 1260 & 6.69 & - & - & - & 0.01 \\
\hline 5 & Isopiperitenone & 1264 & 1266 & 6.79 & 0.18 & 0.07 & 0.20 & 0.36 \\
\hline 6 & Carvacrol & 1269 & 1278 & 7.08 & - & 1.06 & 0.64 & 0.32 \\
\hline 7 & $\begin{array}{l}\text { 3-Cyclopentene-1- } \\
\text { one,2-hydroxy-3- } \\
\text { (3-methyl-2-butenyl)- }\end{array}$ & 1341 & 1346 & 7.76 & 21.91 & 30.54 & 56.72 & 55.08 \\
\hline 8 & Cinerolon & 1645 & 1641 & 8.03 & 0.17 & 0.08 & 0.25 & 0.19 \\
\hline 9 & Caryophyllene & 1418 & 1418 & 8.15 & 7.03 & 5.57 & 3.85 & 2.72 \\
\hline 10 & cis-a-Farnescene & 1465 & 1480 & 8.41 & 1.97 & 1.52 & 1.08 & 1.03 \\
\hline 11 & Germacrene D & 1472 & 1475 & 8.67 & 3.22 & 2.18 & 1.95 & 0.98 \\
\hline 12 & Caryophyllene oxide & 1570 & 1575 & 9.51 & 0.12 & 0.79 & 0.51 & 0.19 \\
\hline
\end{tabular}

(- Absence of compound; RT- Retention time; RI (Obs)- Retention index observed; RI (Lit)- Retention index Listed)

M. piperita: Monoterpenoids (1, 2, 3, 4); Sesquiterpene $(5,6)$

M. longifolia: Monoterpenoids (1, 2, 5, 6, 8, 10); Sesquiterpene (9, 11, 12); Monocyclic terpene ketone (3); Monoterpene ketone (4); Cyclic ketone (7).

$(0.63 \pm 0.01 \%$ and $0.56 \pm 0.01 \%$, respectively) in both $M$. piperita and $M$. longifolia leaves. The $M$. piperita essential oil yield was higher as compared to M. longifolia essential oil.

The monthly variation in essential oil yield could be related to the fact that as the plant ages, the number of leaves and their surface area grows, resulting in the creation of more oil glands and hence a rise in essential oil content. The plant density and harvesting time, according to Mansoori, have a major impact on dry biomass and oil yield production because higher density improves plant vegetative growth and the number of leaves per plant, which enhances light interception and so increases plant essential oil yield. ${ }^{29}$

\section{Essential oil chemical composition}

The volatile and semi-volatile components in the essential oil collected in each month, i.e., from April to May, were investigated using the GC-MS technique that revealed a unique chemical profile of essential oil of both $M$. piperita and $M$. longifolia. A total of six prominent phytochemical compounds (1-menthone, isomenthone, menthol, menthyl acetate, cryophyllene, and germacrene-D) were observed in the essential oil of $M$. piperita from April to July month (Table 2; Fig. 1).

Whereas, in M. longifolia leaves essential oil endo-borneol, $\alpha$ - terpineol, isopiperitenone, piperitone oxide, carvone oxide, 3-cyclopentene-1one, 2-hydroxy-3-(3-methyl-2-butenyl)-, carvacrol, caryophyllene, germacrene $D$, and cis-a-farnescene were observed (Table 2; Fig. 2). 
Most of the phytocompounds found in M. piperita essential oil, such as menthol, menthyl acetate, and menthone, have been reported previously in the literature, with notable differences in essential oil composition and quantity. ${ }^{17,19,30}$ Other phytocompounds found in $M$. longifolia essential oil have also been described in previous papers, except 3-cyclopentene-1-one,2-

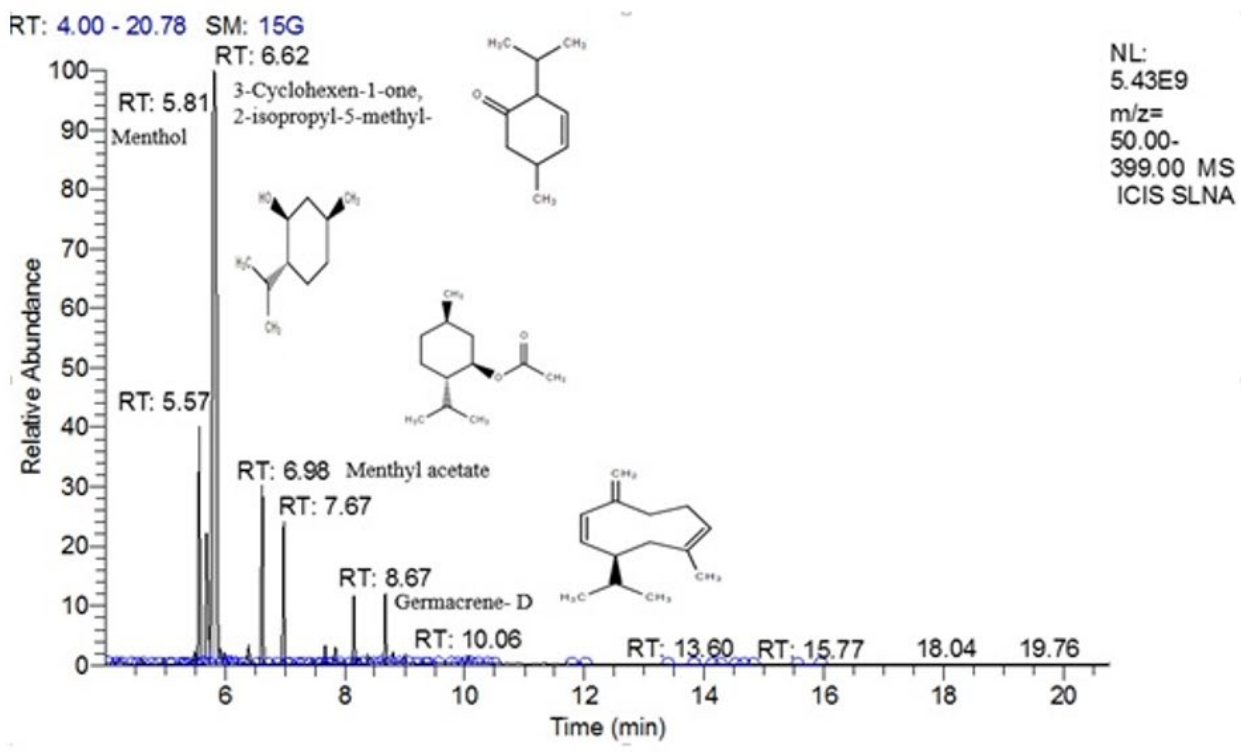

(a)

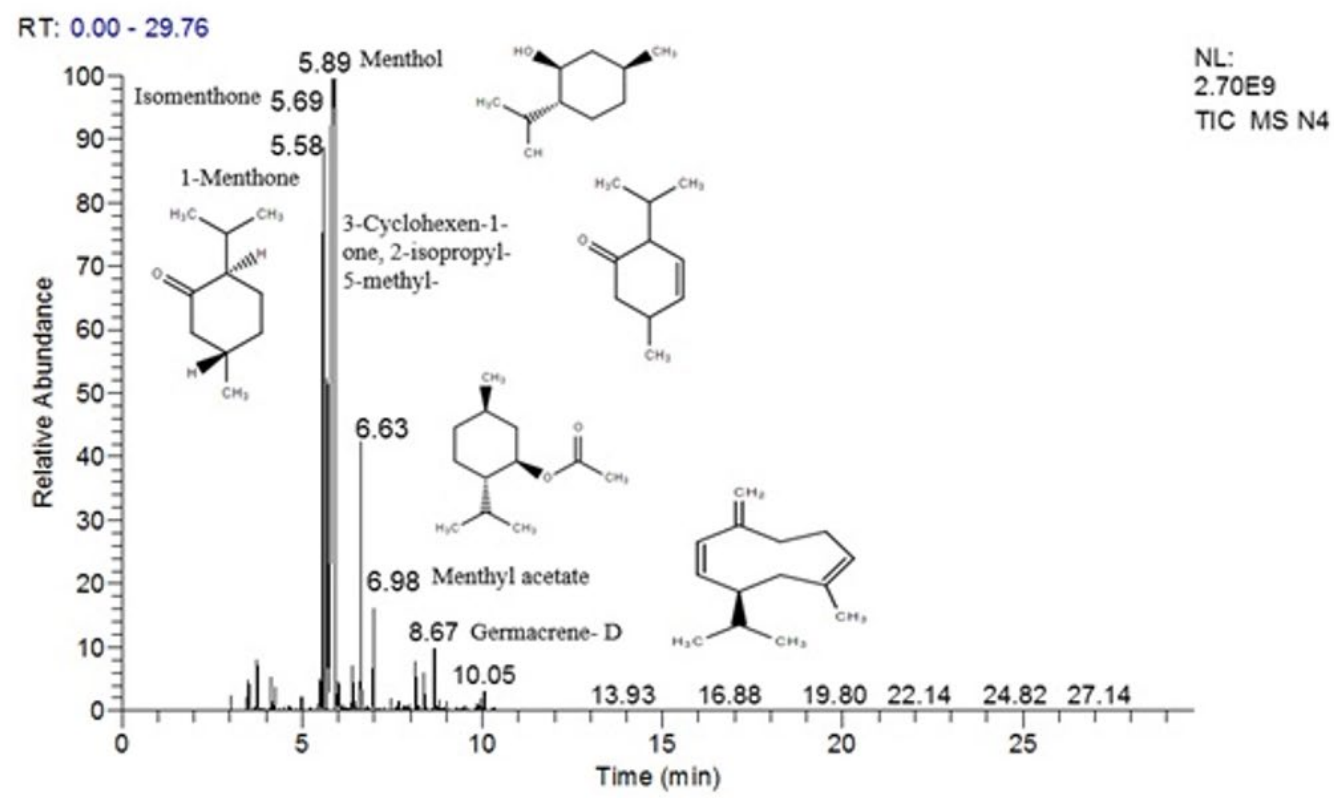

(b)

Fig. 1. GC-MS chromatograms of essential oil of M. piperita obtained from leaves in the month of April (a) and July (b). 
hydroxy-3-(3-methyl-2-butenyl)-, which is a new compound with unknown action. ${ }^{31-33}$ For instance, Verma et al. observed piperitenone oxide, germacrene $D,(E)$-caryophyllene, $\alpha$-humulene, 2 -hydroxy piperitone, thymol, and $\alpha$-longipinene in the $M$. longifolia essential oil collected from the Garhwal region of Western Himalaya. ${ }^{34}$

In the literature, the effect of seasonal change in the essential oil chemical composition from a few Mentha species has

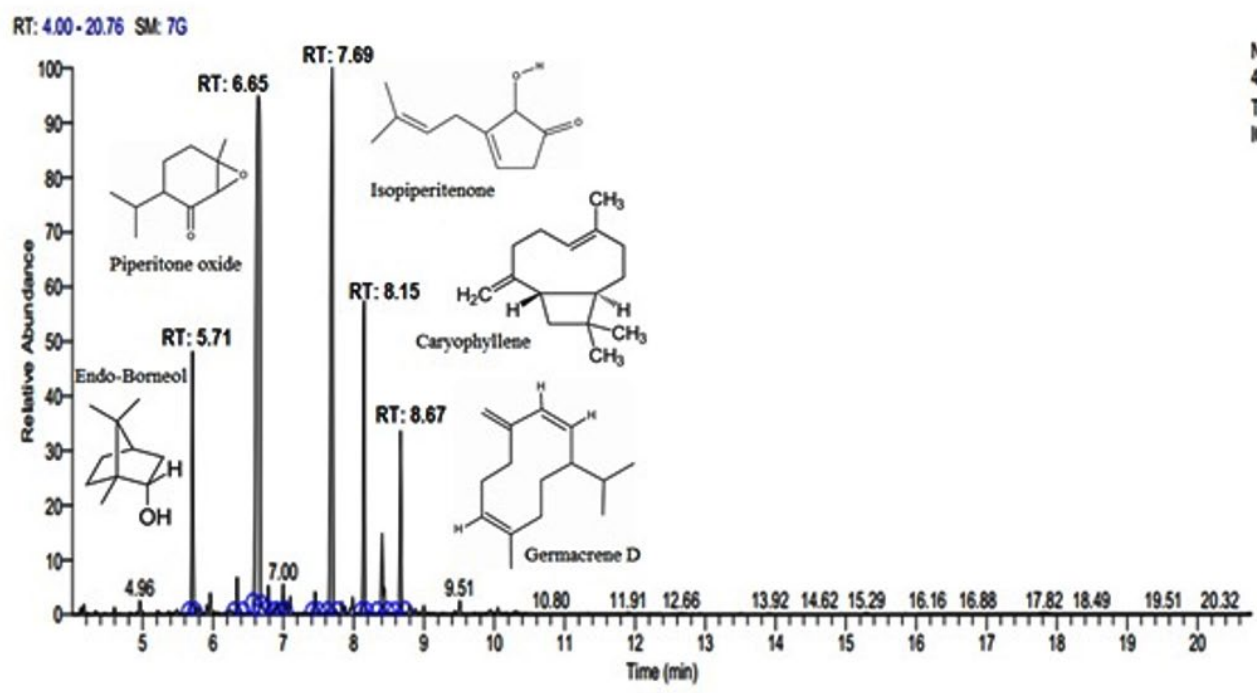

$\mathrm{NL}$

.4359

IC MS

(a)

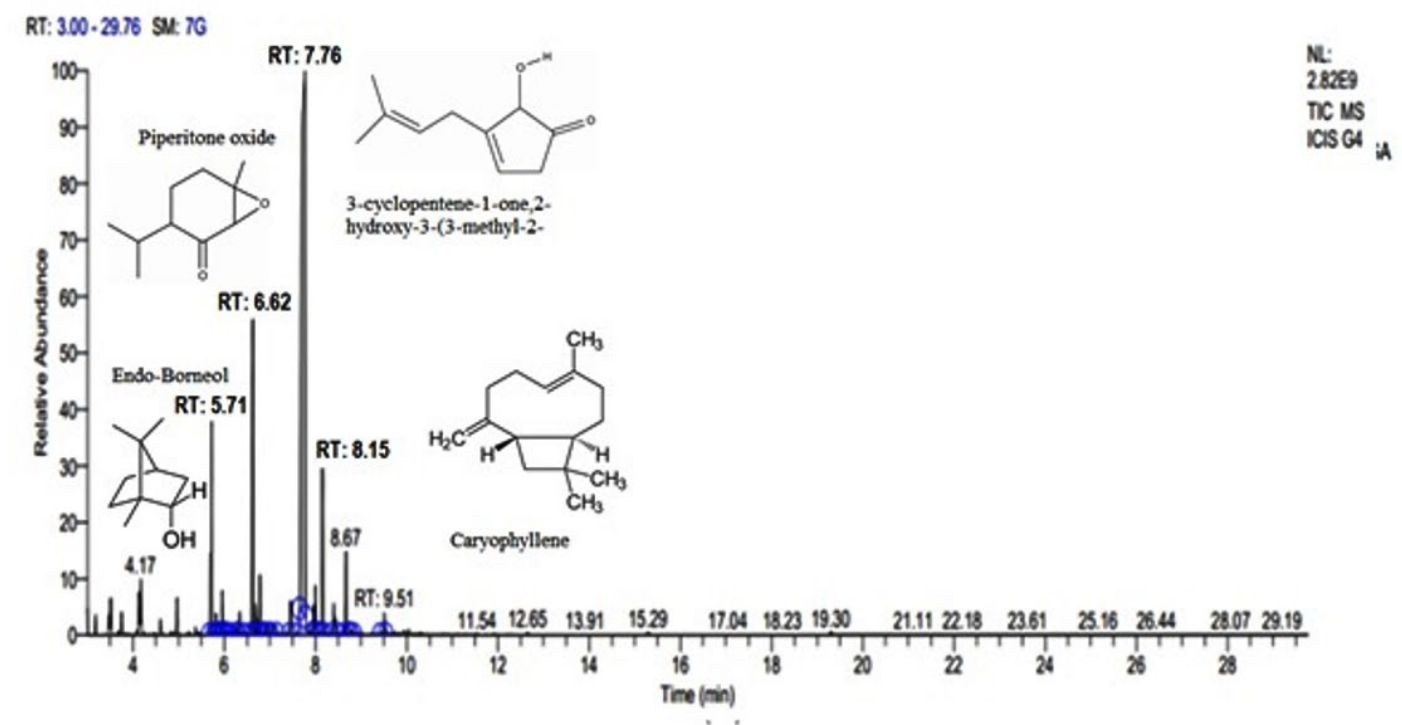

(b)

Fig. 2. GC-MS chromatograms of essential oil of M. longifolia obtained from leaves in the month of April (a) and July (b). 
been documented. ${ }^{23,31-33}$ The current study also revealed variation in the concentration (\%) of phytocompounds detected in the essential oil of both Mentha species in each studied month samples (Table 2 and Fig. 3).
For example, in M. piperita essential oil, the amount of 1-menthone was increased from April month to June month $(7.32 \%-18.32 \%)$ and then decreased in the July month (13.24\%). Menthol was also reduced from April to July

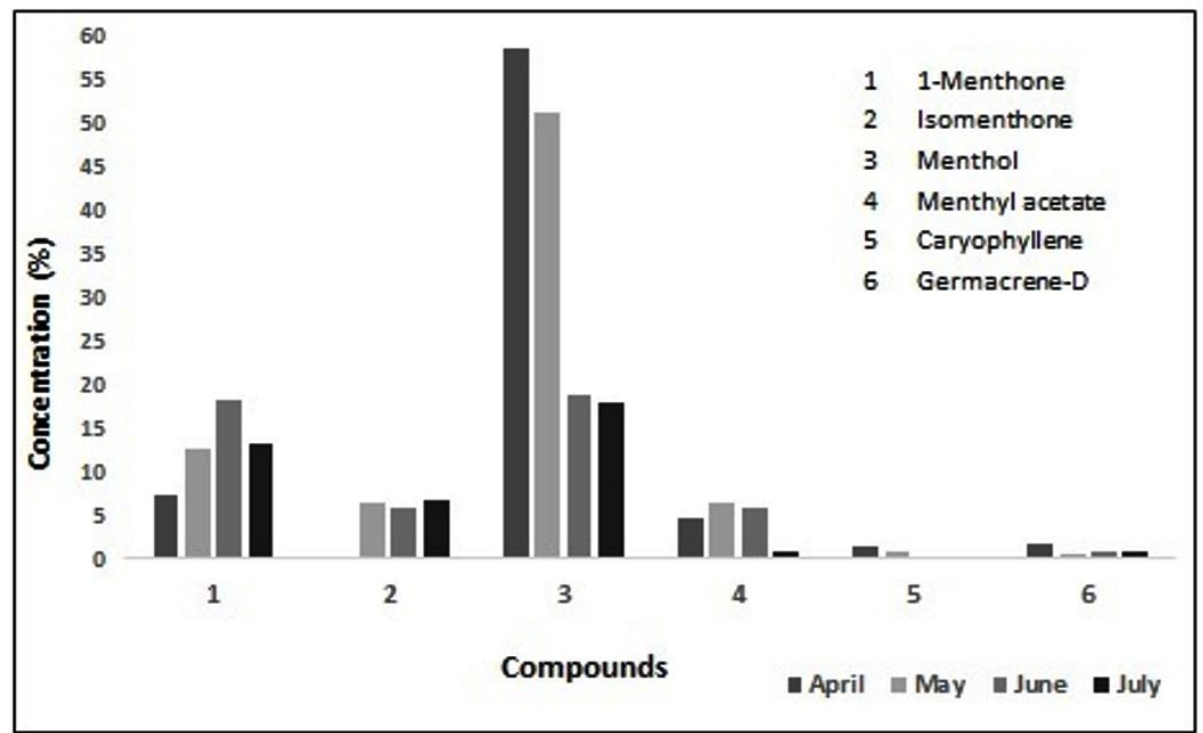

a

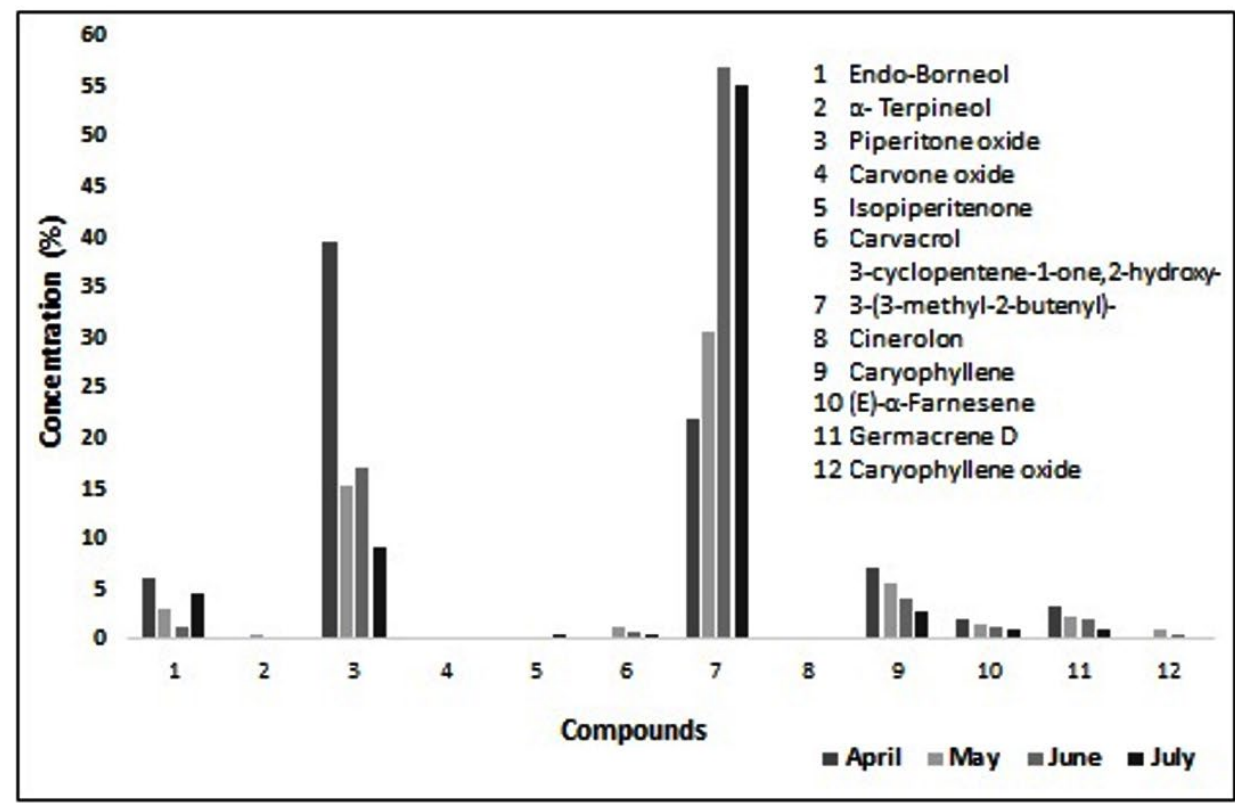

b

Fig. 3. Monthly variation in the composition of essential oil of the leaves of M. piperita (a) and M. longifolia (b). 
Sonam et al. | J Pure Appl Microbiol | 15(4):2229-2243 | December 2021 | https://doi.org/10.22207/JPAM.15.4.45

Table 3. Antibacterial activity of essential oil of leaves of M. piperita and M. longifolia

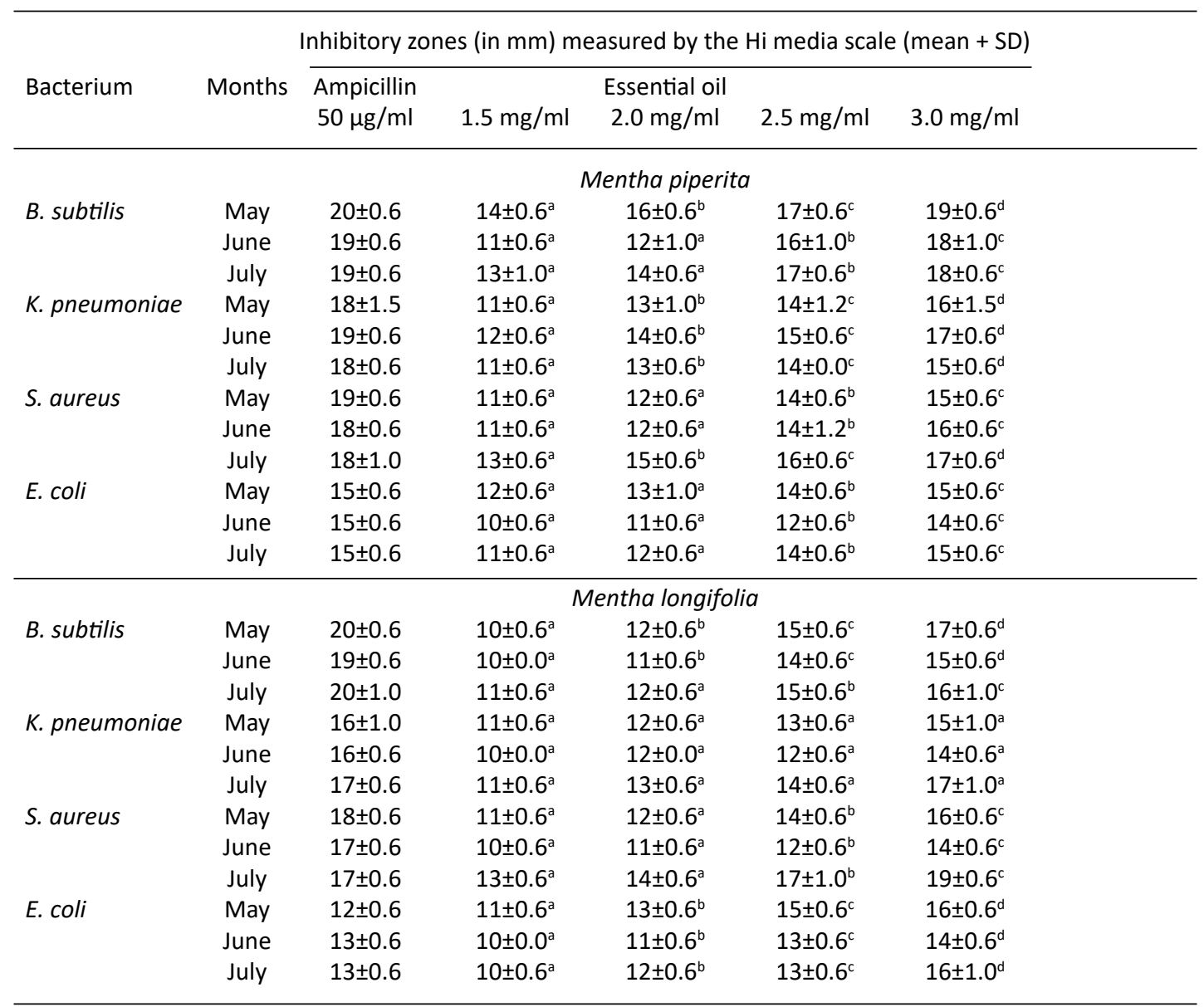

[SD-Standard deviation; Different letters $(a, b, c, d)$ were used when mean values were statistically different $(p<0.05)]$.

(58.43\% - 18.03\%), whereas menthyl acetate was elevated from April to May (4.78\% - 6.35\%) and subsequently declined from June to July ( 58.43 percent-18.03 percent) (5.89\% - 0.72\%). In May and June, there was a higher concentration of menthyl acetate. Similarly, in M. longifolia essential oil, endo-borneol concentration was decreased from April (6.02\%) to June (1.12\%) and suddenly increased in July (4.59\%). The increasing trend of the compound 3-cyclopentene1-one, 2-hydroxy-3-(3-methyl-2-butenyl) was observed from April (21.91\%) to July (55.08\%). In continuation, from April (7.03 \%) to May (5.57\%), the caryophyllene level increased, then declined from June (3.85\%) through July (2.72\%). On the other hand, piperitone oxide (39.31-8.96\%) decreased from April (39.31\%) to May (15.22\%), insignificantly increased in June $(17.08 \%)$ and then decreased in July (8.96 \%) month. The remaining compounds like germacrene $D(3.22-0.98 \%)$ and cis-a-farnescene (1.97-1.-3\%) showed a decreasing trend from April to July month. Fig. 3 shows the increasing and decreasing order of concentration of detected phytocompounds.

In comparison to previous findings, the principal compounds observed in $M$. longifolia oil were menthone, pulegone, limonene, and terpinolenone, but the present investigation revealed that several of these compounds were absent in the $M$. longifolia essential oil. A chemical, 3-cyclopentene-1-one,2-hydroxy-3-(3-methyl-2butenyl)-, was also observed in the GC-MS profile of $M$. longifolia essential oil, which is a new compound with unknown action. Similarly, most researchers identified menthofuran, limonene, and 1,8-cineole as important components in $M$. 
Table 4. Minimum inhibitory concentration (MIC) of M. piperita and M. longifolia leaves essential oil against $B$. subtilis, K. pneumoniae, S. aureus and E. coli

\begin{tabular}{|c|c|c|c|c|c|c|c|c|}
\hline \multirow{3}{*}{ Months } & \multicolumn{8}{|c|}{ MIC of Bacterial strains $(\mathrm{mg} / \mathrm{mL})$} \\
\hline & \multicolumn{2}{|c|}{ B. subtilis } & \multicolumn{2}{|c|}{ K. pneumoniae } & \multicolumn{2}{|c|}{ S. aureus } & \multicolumn{2}{|c|}{ E. coli } \\
\hline & $\overline{\text { Oil }}$ & Ampicillin & $\overline{\text { Oil }}$ & Ampicillin & $\overline{\text { Oil }}$ & Ampicillin & $\overline{\text { Oil }}$ & Ampicillin \\
\hline \multicolumn{9}{|c|}{ Mentha piperita } \\
\hline May & 0.62 & 0.07 & 0.62 & 0.07 & 1.25 & 0.03 & 1.25 & 0.07 \\
\hline June & 1.25 & 0.07 & 1.25 & 0.07 & 1.25 & 0.03 & 2.50 & 0.07 \\
\hline July & 0.62 & 0.07 & 0.62 & 0.07 & 0.62 & 0.03 & 1.25 & 0.07 \\
\hline \multicolumn{9}{|c|}{ Mentha longifolia } \\
\hline May & 0.31 & 0.07 & 0.62 & 0.07 & 0.62 & 0.03 & 0.62 & 0.07 \\
\hline June & 0.62 & 0.07 & 1.25 & 0.07 & 0.62 & 0.03 & 2.50 & 0.07 \\
\hline July & 0.31 & 0.07 & 0.31 & 0.07 & 0.31 & 0.03 & 1.25 & 0.07 \\
\hline
\end{tabular}

piperita essential oil, however, our investigation found none of these chemicals. ${ }^{35,36}$ This difference in the essential oil chemical composition from plant species can be attributed to variation in climatic, edaphic conditions, harvesting period and drying technique, etc. ${ }^{37}$ Additionally, chemical profile is influenced by all such factors that can boost the biosynthesis of some molecules while inhibiting the biosynthesis of others. ${ }^{38}$

\section{Antibacterial activity}

The study revealed that as the concentration of essential oil (M. piperita and $M$. longifolia) increased from $1.5-3.0 \mathrm{mg} / \mathrm{mL}$ the inhibition zone diameter was also increased from May to July month, and fluctuation in the essential oil activity of both Mentha species in each month was extremely minute (Table 3 ).

In addition, $M$. piperita essential oil showed the lowest MIC $(0.62 \mathrm{mg} / \mathrm{mL})$ against $B$. subtilis, K. pneumoniae (MIC - $0.62 \mathrm{mg} / \mathrm{mL}$ ), and E. coli (MIC - $1.25 \mathrm{mg} / \mathrm{mL}$ ) in May and July month harvest, and against S. aureus, (MIC $-0.62 \mathrm{mg} / \mathrm{mL}$ )

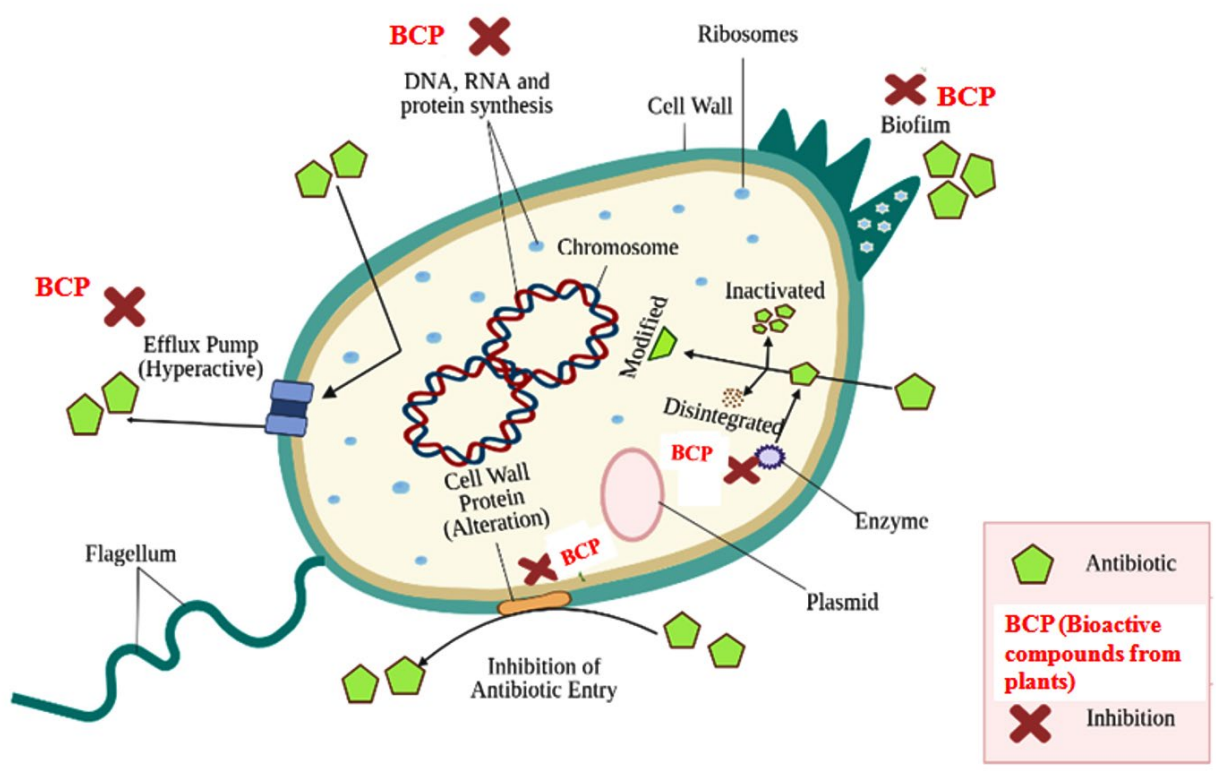

Fig. 4. Antibiotic resistance mechanisms and mode of action of plant bioactive compounds against bacterial strains. Reproduced from ${ }^{48}$ under the Creative Commons Attribution (CC BY) license (http://creativecommons.org/licenses/ by/4.0/). 
Sonam et al. | J Pure Appl Microbiol | 15(4):2229-2243 | December 2021 | https://doi.org/10.22207/JPAM.15.4.45

Table 5. Antifungal activity of essential oil of leaves of $M$. piperita and M. longifolia against $C$. albicans

\begin{tabular}{|c|c|c|c|c|c|c|}
\hline \multirow[t]{2}{*}{ Fungal strains } & \multirow[t]{2}{*}{ Months } & \multicolumn{5}{|c|}{ Inhibitory zones (in $\mathrm{mm}$ ) measured by the Hi media scale (mean+SD) } \\
\hline & & $\begin{array}{c}\text { Fluconazole } \\
50 \mu \mathrm{g} / \mathrm{ml}\end{array}$ & $1.5 \mathrm{mg} / \mathrm{ml}$ & $\begin{array}{c}\text { Essential oil } \\
2.0 \mathrm{mg} / \mathrm{ml}\end{array}$ & $2.5 \mathrm{mg} / \mathrm{ml}$ & $3.0 \mathrm{mg} / \mathrm{ml}$ \\
\hline & & & & lentha piperi & & \\
\hline \multirow[t]{4}{*}{ C. albicans } & May & $12 \pm 0.6$ & $10 \pm 0.6^{\mathrm{a}}$ & $10 \pm 0.6^{a}$ & $12 \pm 0.6^{b}$ & $13 \pm 0.6^{c}$ \\
\hline & June & $12 \pm 0.6$ & $11 \pm 0.6^{\mathrm{a}}$ & $12 \pm 0.0^{\mathrm{a}}$ & $13 \pm 1.0^{b}$ & $15 \pm 0.6^{c}$ \\
\hline & July & $13 \pm 0.6$ & $12 \pm 0.6^{\mathrm{a}}$ & $12 \pm 0.6^{a}$ & $14 \pm 1.0^{\mathrm{b}}$ & $16 \pm 0.6^{c}$ \\
\hline & \multicolumn{6}{|c|}{ Mentha longifolia } \\
\hline \multirow[t]{3}{*}{ C. albicans } & May & $12 \pm 0.6$ & $10 \pm 0.6^{a}$ & $11 \pm 1.0^{\mathrm{a}}$ & $12 \pm 0.6^{b}$ & $13 \pm 1.0^{c}$ \\
\hline & June & $12 \pm 0.0$ & $14 \pm 1.0^{\mathrm{a}}$ & $16 \pm 1.2^{\mathrm{b}}$ & $18 \pm 1.2^{\mathrm{c}}$ & $18 \pm 0.6^{d}$ \\
\hline & July & $13 \pm 1.2$ & $12 \pm 0.6^{\mathrm{a}}$ & $18 \pm 0.0^{b}$ & $18 \pm 0.6^{c}$ & $19 \pm 1.0^{d}$ \\
\hline
\end{tabular}

[SD-Standard deviation; Different letters were used when mean values were statistically different $(p<0.05)]$.

Table 6. Antifungal activity of essential oil of leaves of $M$. piperita and $M$. longifolia against $F$. oxysporum

\begin{tabular}{|c|c|c|c|c|c|}
\hline \multirow[t]{3}{*}{ Method } & \multirow[t]{3}{*}{ Months } & \multicolumn{3}{|c|}{ Essential oil concentration } & \multirow[b]{2}{*}{$3.0 \mathrm{mg} / \mathrm{ml}$} \\
\hline & & $1.5 \mathrm{mg} / \mathrm{ml}$ & $2.0 \mathrm{mg} / \mathrm{ml}$ & $2.5 \mathrm{mg} / \mathrm{ml}$ & \\
\hline & & \multicolumn{3}{|c|}{ \% Inhibition (mean+SD) } & \\
\hline \multirow{4}{*}{$\begin{array}{l}\text { Poison food } \\
\text { technique }\end{array}$} & & & Mentha piperit & & \\
\hline & May & $39.1 \pm 4.06^{a}$ & $48.50 \pm 2.34^{b}$ & $53.92 \pm 2.34^{c}$ & $60.69 \pm 2.34^{d}$ \\
\hline & June & $24.61 \pm 2.03^{a}$ & $32.85 \pm 3.53^{b}$ & $39.92 \pm 3.53^{c}$ & $56.41 \pm 2.03^{d}$ \\
\hline & July & $15.36 \pm 2.25^{\mathrm{a}}$ & $20.56 \pm 2.25^{b}$ & $30.98 \pm 2.25^{c}$ & $44.00 \pm 2.25^{d}$ \\
\hline \multirow{3}{*}{$\begin{array}{l}\text { Dry weight } \\
\text { technique }\end{array}$} & May & $43.22 \pm 0.44^{\mathrm{a}}$ & $50.69 \pm 0.91^{a}$ & $64.95 \pm 1.34^{b}$ & $79.61 \pm 0.40^{c}$ \\
\hline & June & $38.36 \pm 1.03^{\mathrm{a}}$ & $47.56 \pm 1.57^{b}$ & $62.63 \pm 0.57^{c}$ & $74.22 \pm 0.94^{d}$ \\
\hline & July & $28.67 \pm 0.90^{\mathrm{a}}$ & $40.09 \pm 0.87^{b}$ & $60.92 \pm 0.34^{c}$ & $73.22 \pm 0.79^{d}$ \\
\hline \multicolumn{6}{|c|}{ Mentha longifolia } \\
\hline \multirow{3}{*}{$\begin{array}{l}\text { Poisoned food } \\
\text { technique }\end{array}$} & May & $41.72 \pm 2.34^{\mathrm{a}}$ & $48.50 \pm 2.34^{b}$ & $52.56 \pm 2.34^{c}$ & $60.70 \pm 4.69^{d}$ \\
\hline & June & $28.14 \pm 2.03^{\mathrm{a}}$ & $38.74 \pm 2.03^{b}$ & $49.35 \pm 2.04^{c}$ & $58.77 \pm 2.04^{d}$ \\
\hline & July & $18.48 \pm 0.90^{\mathrm{a}}$ & $24.47 \pm 2.25^{b}$ & $36.19 \pm 2.25^{c}$ & $47.91 \pm 2.25^{d}$ \\
\hline \multirow{3}{*}{$\begin{array}{l}\text { Dry weight } \\
\text { method }\end{array}$} & May & $50.63 \pm 0.60^{\mathrm{a}}$ & $66.61 \pm 0.85^{b}$ & $78.17 \pm 0.41^{c}$ & $90.90 \pm 0.79^{d}$ \\
\hline & June & $33.04 \pm 0.77^{a}$ & $47.92 \pm 0.75^{b}$ & $77.57 \pm 1.20^{c}$ & $87.90 \pm 0.76^{d}$ \\
\hline & July & $31.55 \pm 1.07^{\mathrm{a}}$ & $43.89 \pm 0.49^{b}$ & $71.56 \pm 0.87^{c}$ & $85.89 \pm 0.95^{d}$ \\
\hline
\end{tabular}

[SD-Standard deviation; Different letters were used when mean values were statistically different $(p<0.05)]$.

in July month. Subsequently, May and July month harvest was found to be most effective against $E$. coli with MIC-1.25 mg/mL (Table 4). On the other hand, M. longifolia essential oil (May and July month harvest) showed the lowest MIC $(0.31 \mathrm{mg} /$ $\mathrm{mL}$ ) against $B$. subtilis. Further, a similar MIC was observed against $S$. aureus and $K$. pneumoniae with the July month harvest (Table 4).

The M. piperita and $M$. longifolia essential oils were observed to be extra effective against $B$. subtilis, K. pneumoniae, and S. aureus than E. coli.
The present findings are consistent with previous research. ${ }^{39-45}$

Although, the effect of season on the antibacterial property of $M$. longifolia and $M$. piperita is known, there is no report on the ideal harvesting time for $M$. longifolia and $M$. piperita in terms of antibacterial potential of essential oil within one growing season. ${ }^{32,37,46}$ In contrary to previous reports, in this study almost similar activity was reported against Gram positive as well as Gram negative strains. As per existing 
Table 7. MIC values of $M$. piperita and $M$ longifolia leaves essential oil against C. albicans and $F$. oxysporum

\begin{tabular}{|c|c|c|c|c|}
\hline \multirow[t]{3}{*}{ Months } & \multicolumn{4}{|c|}{ MIC of fungal strains $(\mathrm{mg} / \mathrm{mL})$} \\
\hline & \multicolumn{2}{|c|}{ C. albicans } & \multicolumn{2}{|c|}{ F. oxysporum } \\
\hline & $\begin{array}{l}\text { Essential } \\
\text { oil }\end{array}$ & Ampicillin & $\begin{array}{l}\text { Essential } \\
\text { oil }\end{array}$ & $\begin{array}{c}\text { Hygromycin } \\
\text { B }\end{array}$ \\
\hline \multicolumn{5}{|c|}{ Mentha piperita } \\
\hline May & 1.25 & 0.15 & 0.62 & 0.03 \\
\hline June & 0.62 & 0.15 & 0.62 & 0.03 \\
\hline July & 0.31 & 0.15 & 1.25 & 0.03 \\
\hline \multicolumn{5}{|c|}{ Mentha longifolia } \\
\hline May & 0.62 & 0.15 & 0.31 & 0.03 \\
\hline June & 0.31 & 0.15 & 0.62 & 0.03 \\
\hline July & 0.15 & 0.15 & 0.62 & 0.03 \\
\hline
\end{tabular}

literature, Gram positive bacterial strains are more susceptible to antibacterial agents as compared to Gram negative ones as the latter has a lipid bilayer that protects them against antimicrobials. ${ }^{47}$ The bioactive content of $M$. longifolia and $M$. piperita essential oils is considered to be responsible for their antibacterial properties.

Balkrishna et al. ${ }^{48}$ described antibiotic resistance mechanisms such as molecular target transformation, efflux pump hyperactivity, biofilm growth, enzyme induced destruction, and drug transformation. They demonstrated that, antibacterial activity of plants is linked to their bioactive composition, and can be mediated by inhibiting efflux pump expression level, protein and DNA synthesis, biofilm, and others as shown in Fig. 4.

The essential oils of Mentha spp. might work through the mechanisms described above due to diverse bioactive components.

Fungicidal activity

The analysis revealed that as the concentration of the essential oil $(0.5 \mathrm{mg} / \mathrm{mL}-3.0$ $\mathrm{mg} / \mathrm{mL}$ ) increased, inhibition of fungal growth also increased (Tables 5 and 6 ). The lowest MIC values were observed with essential oil of $M$. piperita against $C$. albicans in July and May months (MIC$0.31 \mathrm{mg} / \mathrm{mL}$ ).

Whereas, the essential oil extracted in June and May months showed the same MIC value of $0.62 \mathrm{mg} / \mathrm{mL}$ against F. oxysporum (Table 7). On the other hand, the M. longifolia essential oilMIC values revealed the maximum fungicidal activity against $C$. albicans in July month (MIC-1.5 mg/ $\mathrm{mL}$ ), whereas, essential oil of May month harvest showed maximum antifungal activity (MIC-1.5 mg/ $\mathrm{mL}$ ) against $F$. oxysporum (Table 7). These findings proved that both Mentha species essential oil were more efficient against Candida albicans than $F$. oxysporum. Additionally, M. longifolia essential oil has stronger fungicidal action than $M$. piperita essential oil, similar to the antibacterial results. Hussain et al. observed the maximum antifungal activity of the $M$. longifolia oil in the summer season and $M$. piperita oil in the winter season against $F$. oxysporum. ${ }^{33}$ Kizil et al. also observed the significant antibacterial effect of $M$. piperita essential oil against C. albicans, and E. coli. ${ }^{49}$

In the light of existing literature, it was found that, the antifungal and antibacterial potential of essential oil is attributed to the presence of some phytoconstituents with various mechanisms including hydrophobicity. ${ }^{50}$ In addition, the mode of action of plant bioactive content is still unknown; it is thought that they interfere with cell membrane organization, resulting in a drop in membrane potential and a lower amount of ATP synthesis. ${ }^{48}$

The antibacterial effect of $M$. piperita oil is due to menthol, menthone, piperitenone oxide, and carvone, according to the available literature. ${ }^{34}$ Subsequently, according to Zouari-Bouassida et al. monoterpenoids are responsible for the antimicrobial potential of $M$. piperita essential oil. ${ }^{45}$ Similarly, in M. longifolia essential oil the antimicrobial activity is due to the existence of menthol, menthone, piperitone oxide, carvone, etc. ${ }^{33}$ However, some of these components were missing from $M$. longifolia essential oil obtained in the northwestern Himalaya. The compounds observed during the present study were piperitone oxide, 3-cyclopentene-1-one,2-hydroxy-3-(3methyl-2-butenyl)-, borneol, caryophyllene, cis-afarnesene, germacrene $D$, etc. and most of these compounds have been reported in the literature with various biological activities. ${ }^{19,31,39,41,51-54}$ Hence, the variation in antimicrobial potential of the essential oils harvested in the examined months could be related to variations in the quantity of these phytoconstituents in each month from April to July. 


\section{CONCLUSION}

In conclusion, M. piperita essential oil harvested in July month was more effective against Klebsiella pneumoniae, Staphylococcus aureus and Candida albicans, whereas May month harvest showed good activity against Bacillus subtilis, Escherichia coli, and Fusarium oxysporum. Similarly, M. longifolia essential oil from the July month harvest was more potent against $K$. pneumoniae, E. coli, and Candida albicans, as compared to May month harvest (moderately effective against $B$. subtilis, and $F$. oxysporum). This may be due to the cumulative effect of biologically active phytocompounds such as menthol, isomenthone, piperitone oxide, carvone oxide, and others, which accumulated in July, and germacrene D, caryophyllene oxide, caryophyllene, a-terpineol, and others in May. As a result, the harvesting time was found to be a key player for the antimicrobial potential of Mentha essential oils, like M. piperita, M. longifolia essential oil can be utilized in the pharmaceutical, perfumery, and food industries.

\section{ACKNOWLEDGMENTS}

None.

\section{CONFLICT OF INTEREST}

The authors declare that there is no conflict of interest.

\section{AUTHORS' CONTRIBUTION}

All authors listed have made a substantial, direct and intellectual contribution to the work, and approved it for publication.

\section{FUNDING}

None.

\section{DATA AVAILABILITY}

All datasets generated or analyzed during this study are included in the manuscript

\section{ETHICS STATEMENT}

Not applicable.

\section{REFERENCES}

1. Segev D, Nitzan N, Chaimovitsh D, Eshel A, Dudai N. Chemical and morphological diversity in wild populations of Mentha longifolia in Israel. Chem
Biodivers. 2012;9(3):577-588. doi: 10.1002/ cbdv.201100108

2. Balla OY, Ali MM, Garbi MI, Kabbashi AS. Chemical composition and antimicrobial activity of essential oil of Mentha viridis. Biochem Mol Bio. 2017;2(5):60-66. doi: 10.11648/j.bmb.20170205.12

3. Mikaili P, Mojaverrostami S, Moloudizargari S, Aghajanshakeri S. Pharmacological and therapeutic effects of Mentha longifolia $\mathrm{L}$. and its main constituent, menthol. Anc Sci Life. 2013;33(2):131-138. doi: 10.4103/0257-7941.139059

4. Sousa PJ, Linard CF, Azevedo-Batista D, Oliveira AC, Coelho-de-Souza AN, Leal-Cardoso JH. Antinociceptive effects of the essential oil of Mentha $x$ villosa leaf and its major constituent piperitone oxide in mice. $B r a z$ J Med Biol Res. 2009;42(7):655-659. doi: 10.1590/ S0100-879X2009000700010

5. Tsai $M L, W u C T$, Lin TF, Lin $W C$, Huang $Y C$, Yang $C H$. Chemical composition and biological properties of essential oils of two mint species. Trop J Pharm Res. 2013;12(4):577-582. doi: 10.4314/tjpr.v12i4.20

6. Abbaszadeh B, Valadabadi SA, Farahani HA, Darvishi $\mathrm{HH}$. Studying of essential oil variations in leaves of Mentha species. Afr J Plant Sci. 2009;3:217-221.

7. Paul R, Animesh DK. An updated overview on Peppermint (Mentha piperita L.). Int Res J Pharm. 2011;2(8):1-10.

8. Eftekhari A, Khusro A, Ahmadian E, Dizaj SM, Hasanzadeh A, Cucchiarini M. Phytochemical and nutra-pharmaceutical attributes of Mentha spp.: A comprehensive review. Arab J Chem. 2021;14(5):103106. doi: 10.1016/j.arabjc.2021.103106

9. Ali B, Al-Wabel NA, Shams S, Ahamad A, Khan SA, Anwar F. Essential oils used in aromatherapy: A systemic review. Asian Pac J Trop Biomed. 2015;5(8):601-611. doi: 10.1016/j.apjtb.2015.05.007

10. Abu-Shanab B, Adwan GM, AbuSafiya D, Jarrar N, Adwan K. Antibacterial activities of some plant extracts utilized in popular medicine in Palestine. Turk J Biol. 2005;28(2-4):99-102.

11. Kelen M, Tepe B. Chemical composition, antioxidant and antimicrobial properties of the essential oils of three Salvia species from Turkish flora. Bioresour Technol. 2008;99(10):4096-4104. doi: 10.1016/j. biortech.2007.09.002

12. Celiktas OY, Kocabas EEH, Bedir E, Sukan FV, Ozek $\mathrm{T}$, Baser KHC. Antimicrobial activities of methanol extracts and essential oils of Rosmarinus officinalis, depending on location and seasonal variations. Food Chem. 2007;100(2):553-559. doi: 10.1016/j. foodchem.2005.10.011

13. Singh P, Pandey AK. Prospective of essential oils of the genus Mentha as biopesticides: A review. Front Plant Sci. 2018;9:1-14. doi: 10.3389/fpls.2018.01295

14. Chauhan RS, Kaul MK, Shahi AK, Kumar A. Ram G, Tawa A. Chemical composition of essential oils in Mentha spicata L. accession [IIIM (J) 26] from North West Himalayan region, India. Ind Crops Prod. 2009;29(23):654-656. doi: 10.1016/j.indcrop.2008.12.003

15. Hameed IH, Hussein HJ, Kareem MA, Hamad NS. Identification of five newly described bioactive chemical compounds in methanolic extract of 
Mentha viridis by using gas chromatography-mass spectrometry (GC-MS). J Pharmacogn Phytotherapy. 2015;7(7):107-125. doi: 10.5897/JPP2015.0349

16. Tyagi AK, Malik A. Antimicrobial action of essential oil vapours and negative air ions against Pseudomonas fluorescence. Int J Food Microbiol. 2010;143(3):205210. doi: 10.1016/j.ijfoodmicro.2010.08.023

17. Desam NR, Al-Rajab AJ, Sharma M, Mylabathula MM, Gowkanapalli RR, Albratty M. Chemical constituents, in vitro antibacterial and antifungal activity of Mentha x piperita L. (peppermint) essential oils. J King Saud Univ Sci. 2019;31(4):528-533. doi: 10.1016/j. jksus.2017.07.013

18. Iscan G, Kirimer N, Kurkcuoglu M, Baser HC, Demirci F. Antimicrobial screening of Mentha piperita essential oils. J Agric Food Chem. 2002;50(14):3943-3946. doi: 10.1021/jf011476k

19. Sokovic $M$, Vukojevic J, Marin P, Brkic D, Vajs V, Van Griensven L. Chemical composition of essential oils of Thymus and Mentha species and their antifungal activities. Molecules. 2009;14(1):238-249. doi: 10.3390/molecules 14010238

20. Abbaszadeh B, Valadabadi HA, Moaveni P. Investigation of variations of the morphological values and flowering shoot yield in different mint species at Iran. $J$ Hortic For. 2009;1(7):109-112. doi: 10.5897/JHF.9000073

21. Erum $S$, Naeemullah M, Masood S. Phenotypic variation among Mentha spp. Pak J Agric Res. 2012;25(1):55-62.

22. Clevenger JF. Apparatus for the determination of volatile oil. J Am Pharm Assoc. 1928;17(4):345-349. doi: 10.1002/jps.3080170407

23. Okut N, Yagmur M, Selcuk N, Yildirim B. Chemical composition of essential oil of Mentha longifolia L. subsp. longifolia growing wild. PakJ Bot. 2017;49:525529.

24. Perez C, Paul M, Bazerque P. Antibiotic assay by agar-well diffusion method. Acta Biol Med Exp. 1990;15:113-115.

25. Bauer AW, Kirby WMM, Sherris JC, Turck M. Antibiotic susceptibility testing by a standardized single disc method. Am J Clin Pathol. 1966;45(4):493-496. doi: 10.1093/ajcp/45.4_ts.493

26. Ramaiah AK, Garampalli RK. In vitro antifungal activity of some plant extracts against Fusarium oxysporum and F. lycopersici. Asian J Plant Sci Res. 2015;5:22-27.

27. Premanath R, Devi NL. Antibacterial, antifungal, and antioxidant activities of Andrographis paniculata Nees. leaves. Int J Pharm Sci Res. 2011;2:2091-2099.

28. Silverio $M$, Del-Vechio-Vieira $G$, Pinto $M$, Alves $M$, Sousa O. Chemical composition and biological activities of essential oils of Eremanthus erythropappus (DC) McLeisch (Asteraceae). Molecules. 2013;18(8):97859796. doi: 10.3390/molecules18089785

29. Mansoori M. The effect of plant density and harvesting time on growth and essential oil of Peppermint (Mentha piperita L.). J Med Biol Eng. 2014;3(2):113116. doi: 10.12720/jomb.3.2.113-116

30. Shahi AK, Chandra S, Dutt P, Kaul BL, Tava A, Avato P. Essential oil composition of Mentha x piperita L. from different environments of North India. Flavour Fragr J. 1999;14(1):5-8.
31. Hussain Al, Anwar F, Sherazi ST, Przybylski R. Chemical composition, antioxidant and antimicrobial activities of basil (Ocimum basilicum) essential oils depends on seasonal variations. Food Chem. 2008;108(3):986-995. doi: 10.1016/j.foodchem.2007.12.010

32. Hussain Al, Anwar F, Nigam PS, Ashrafd M, Gilanif AH. Seasonal variation in content, chemical composition and antimicrobial and cytotoxic activities of essential oils from four Mentha species. I Sci Food Agric. 2010;90(11):1827-1836. doi: 10.1002/jsfa.4021

33. Niksic H, Kovac-Besovic E, Duric K, Korac N, Omeragic $E$, Muratovic $S$. Seasonal variation in content and chemical composition of essential oils from leaves of Mentha longifolia Huds. (Lamiaceae). Bull Chem Technol Bosnia Herzegovina. 2014;43:29-34.

34. Verma, RS, Pandey V, Chauhan A, Tiwari R. Essential oil composition of Mentha longifolia (L.) L. collected from Garhwal region of Western-Himalaya. J Essent Oil Bearing Plants. 2015;18(4):957-966. doi: 10.1080/0972060X.2014.897594

35. Saharkhiz MJ, Motamedi M, Zomorodian K, Pakshir K, Miri R, Hemyari K. Chemical composition, antifungal and antibiofilm activities of the essential oil of Mentha piperita L. Int Sch Res Notices. 2012;2012:718645. doi: 10.5402/2012/718645

36. Moghaddam M, Pourbaige M, Tabar HK, Farhadi N, Hosseini SM. Composition and antifungal activity of peppermint (Mentha piperita) essential oil from Iran. J Essent Oil Bearing Plants. 2013;16(4):506-512. doi: 10.1080/0972060X.2013.813265

37. Loziene $K$, Venskutonis PR. Influence of environmental and genetic factors on the stability of essential oil composition of Thymus pulegioides. Biochem Syst Ecol. 2005;33(5):517-525. doi: 10.1016/j.bse.2004.10.004

38. Barnola LF, Cedeno A. Inter-population differences in the essential oils of Pinus carbine needles. Biochem Syst Ecol. 2000;28(10):923-931. doi: 10.1016/S03051978(00)00036-3

39. Gulluce M, Sahin F, Sokmen MU, et al. Antimicrobial and antioxidant properties of the essential oils and methanol extract from Mentha longifolia L. ssp. longifolia. Food Chem. 2007;103(4):1449-1456. doi: 10.1016/j.foodchem.2006.10.061

40. Niksic H, Kovac-Besovic E, Makarevic E, Duric K. Chemical composition, antimicrobial and antioxidant properties of Mentha longifolia (L.) Huds. essential oil. J Health Sci. 2012;2(3):192-200. doi: 10.17532/ jhsci.2012.38

41. Mkaddem M, Bouajila J, Ennajar M, Lebrihi A, Mathieu F, Romdhane M. Chemical composition and antimicrobial and antioxidant activities of Mentha (Iongifolia L, viridis) essential oils. J Food Sci. 2009;74(7):358-363. doi: 10.1111/j.1750-3841.2009.01272.x

42. Hajlaoui $H$, Trabelsi N, Noumi E, et al. Biological activities of the essential oils and methanol extract of two cultivated mint species (Mentha longifolia and Mentha pulegium) used in the Tunisian folkloric medicine. World J Microbiol Biotechnol. 2009;25(12):2227-2238. doi: 10.1007/s11274-009-0130-3

43. Andogan BC, Baydar H, Kaya S, Demirci M, Ozbasar D, Mumcu E. Antimicrobial activity and chemical composition of some essential oils. Arch Pharm Res. 
2002;25(6):860-864. doi: 10.1007/BF02977005

44. Zaidi S, Dahiya P. In vitro antimicrobial activity, phytochemical analysis and total phenolic content of essential oil from Mentha spicata and Mentha piperita. Int Food Res J. 2015;22(6):2440-2445.

45. Moosavi-Nasab M, Saharkhiz MJ, Ziaee E, Moayedi F, Koshani R, Azizi R. Chemical compositions and antibacterial activities of five selected aromatic plants essential oils against food-borne pathogens and spoilage bacteria. J Essent Oil Res. 2016;28(3):241-251. doi: 10.1080/10412905.2015.1119762

46. Zouari-Bouassida K, Trigui M, Makni S, Jlaiel L, Tounsi $\mathrm{S}$. Seasonal variation in essential oils composition and the biological and pharmaceutical protective effects of Mentha longifolia leaves grown in Tunisia. Biomed Res Int. 2018;2018:7856517. doi: 10.1155/2018/7856517

47. Beristain-Bauza SDC, Hernandez-Carranza P, Cid-Perez TS, Avila-Sosa R, Ruiz-Lopez II, OchoaVelasco CE. Antimicrobial Activity of Ginger (zingiber officinale) and Its Application in Food Products. Food Rev Int. 2019;35(5):407-426. doi: 10.1080/87559129.2019.1573829

48. Balkrishna A, Rohela A, Kumar A, et al. Mechanistic insight into antimicrobial and antioxidant potential of Jasminum Species: A herbal approach for disease management. Plants. 2021;10(6):1-25. doi: 10.3390/ plants10061089
49. Kizil S, Hasimi N, Tolan V, Kilinc E, Yuksel U. Mineral content, essential oil components and biological activity of two Mentha species ( $M$. piperita L., M. spicata L.,). Turkish J Field Crops. 2010;15(2):148-153.

50. Lv $F$, Liang $H$, Yuan $Q$, Li C. In vitro antimicrobial effects and mechanism of action of selected plant essential oil combinations against four food-related microorganisms. Food Res Int. 2011;44(9):3057-3064. doi: 10.1016/j.foodres.2011.07.030

51. Romagnoli C, Bruni R, Andreotti E, Rai MK, Vicentini $\mathrm{CB}$, Mares $\mathrm{D}$. Chemical characterization and antifungal activity of essential oil of capitula from wild Indian Tagetes patula L. Protoplasma. 2005;225(1-2):57-65. doi: 10.1007/s00709-005-0084-8

52. Dahham S, Tabana $\mathrm{Y}$, Iqbal M, et al. The anticancer, antioxidant, and antimicrobial properties of the sesquiterpene $\beta$-caryophyllene from the essential oil of Aquilaria crassna. Molecules. 2015;20(7):1180811829. doi: 10.3390/molecules 200711808

53. Cote $\mathrm{H}$, Boucher MA, Pichette A, Legault J. Antiinflammatory, antioxidant, antibiotic, and cytotoxic activities of Tanacetum vulgare $L$. essential oil and its constituents. Medicine. 2017;4(2):1-9. doi: 10.3390/ medicines 4020034

54. Khaleel C, Tabanca N, Buchbauer G. $\alpha$ - Terpineol, a natural monoterpene: A review of its biological properties. Open Chem. 2018;16(1):349-361. doi: 10.1515/chem-2018-0040 